\title{
Toxigenic potential and antimicrobial susceptibility of Bacillus cereus group bacteria isolated from Tunisian foodstuffs
}

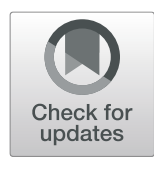

Maroua Gdoura-Ben Amor ${ }^{1,2}$, Sophie Jan², Florence Baron ${ }^{2}$, Noël Grosset ${ }^{2}$, Antoine Culot ${ }^{2,3}$, Radhouane Gdoura ${ }^{1}$, Michel Gautier ${ }^{2}$ and Clarisse Techer $^{3}$

\begin{abstract}
Background: Despite the importance of the B. cereus group as major foodborne pathogens that may cause diarrheal and/or emetic syndrome(s), no study in Tunisia has been conducted in order to characterize the pathogenic potential of the $B$. cereus group. The aim of this study was to assess the sanitary potential risks of 174 B. cereus group strains isolated from different foodstuffs by detecting and profiling virulence genes ( $h b / A$, $h b / B, h b / C, h b l D, n h e A, n h e B, n h e C, c y t K$, bceT and ces), testing the isolates cytotoxic activity on Caco-2 cells and antimicrobial susceptibility towards 11 antibiotics.

Results: The entertoxin genes detected among B. cereus isolates were, in decreasing order, nheA (98.9\%), nheC (97.7\%) and nheB (86.8\%) versus hblC (54.6\%), hblD (54.6\%), hblA (29.9\%) and hblB (14.9\%), respectively encoding for Non-hemolytic enterotoxin (NHE) and Hemolysin BL (HBL). The isolates are multi-toxigenic, harbouring at least one gene of each NHE and HBL complexes associated or not to bceT, cytK-2 and ces genes. Based on the incidence of virulence genes, the strains were separated into 12 toxigenic groups. Isolates positive for cytK $(37,9 \%)$ harbored the cytK-2 variant. The detection rates of bceT and ces genes were 50.6 and $4 \%$, respectively. When bacteria were incubated in BHI-YE at $30^{\circ} \mathrm{C}$ for $18 \mathrm{~h}$ and for $5 \mathrm{~d}, 70.7$ and $35 \%$ of the strains were shown to be cytotoxic to Caco-2 cells, respectively. The cytotoxicity of B. cereus strains depended on the food source of isolation. The presence of virulence factors is not always consistent with cytotoxicity. However, different combinations of enterotoxin genetic determinants are significantly associated to the cytotoxic potential of the bacteria. All strains were fully sensitive to rifampicin, chloramphenicol, ciprofloxacin, and gentamycin. The majority of the isolates were susceptible to streptomycin, kanamycin, erythromycin, vancomycin and tetracycline but showed resistance to ampicillin and novobiocin.
\end{abstract}

Conclusion: Our results contribute data that are primary to facilitate risk assessments in order to prevent food poisoning due to B. cereus group.

Keywords: Bacillus cereus, Foodstuffs, Virulence genes, Cytotoxicity, Antibiotic resistance

\footnotetext{
* Correspondence: marwagdoura50@yahoo.fr

'Laboratory Research of Toxicology-Microbiology Environmental and Health

LR17ES06, Sciences Faculty of Sfax, University of Sfax, Sfax, Tunisia

${ }^{2}$ Equipe Microbiologie, Agrocampus Ouest, INRA, UMR1253 Science et

Technologie du Lait et de l'CEuf, Rennes, France

Full list of author information is available at the end of the article
}

C The Author(s). 2019 Open Access This article is distributed under the terms of the Creative Commons Attribution 4.0 International License (http://creativecommons.org/licenses/by/4.0/), which permits unrestricted use, distribution, and reproduction in any medium, provided you give appropriate credit to the original author(s) and the source, provide a link to the Creative Commons license, and indicate if changes were made. The Creative Commons Public Domain Dedication waiver (http://creativecommons.org/publicdomain/zero/1.0/) applies to the data made available in this article, unless otherwise stated. 


\section{Background}

B. cereus group bacteria, given their widespread nature, can be found in different types of foodstuffs. These bacteria are usually associated with two types of issues, one related to foodborne outbreaks and another one related to food spoilage. The contamination of foods with $B$. cereus group bacteria may lead to food poisoning events that usually occur under the emetic and/or the diarrheal syndromes [1]. These foodborne outbreaks are generally benign and spontaneously resolved. However, B. cereus group bacteria may also occasionally lead to hospitalization or even death of immunosuppressed people [2-6]. The emetic type of food poisoning is caused by the ingestion of cereulide, which is preformed in food. This toxin is a small cyclic dodecadepsipeptide encoded by the ces gene. The cereulide is heat and $\mathrm{pH}$ stable, highly resistant to protease activity and it remains active through the gastro-intestinal passage [7]. The diarrheal type of food poisoning is caused by one or several heat-labile enterotoxins that can be formed in in the small intestine. The enterotoxins produced by $B$. cereus group bacteria that are recognized as playing a major role in the diarrheal disease are the Hemolysin $\mathrm{BL}(\mathrm{HBL})$ encoded by $h b l A, h b l B, h b l C$, and $h b l D$; the NonHemolytic Enterotoxin (NHE) encoded by nheA, nheB and $n h e C$, and the Cytotoxin $\mathrm{K}$ (CytK) encoded by cytK $[8,9]$. Two CytK variants encoded by $c y t K-1$ and $c y t K-2$ genes, have been described by Guinebretière et al. [10] and Castiaux et al. [11]. CytK-1 shows $89 \%$ protein sequence homology with that of CytK-2, but carries much higher toxicity.

Apart from HBL, NHE and CytK, also Enterotoxin T that is encoded by the $b c e T$ gene, belongs to the group of diarrhoeal enterotoxins. Contribution to food poisoning of BceT enterotoxin [12], could never be confirmed and as a result of later studies the reported activity and identity of BceT as entertoxin is questionable [13, 14]. It was suggested that the $b c e T$ gene product does not possess biological activity and cannot contribute to outbreaks [13], and seems to be a cloning artifact [14].

The actual risk of food poisoning due to the $B$. cereus group depends on the level of expression of the virulence genes [15-18]. The emetic and the diarrheal syndromes can occur when the bacterial cell concentration reaches a level of 5 to $8 \log _{10} \mathrm{CFU} / \mathrm{g}$ and of 5 to 7 $\log _{10} \mathrm{CFU} / \mathrm{g}$, respectively $[19,20]$. Therefore, it is generally advised to food industries that foods with $10^{5} \mathrm{CFU} / \mathrm{g}$ of $B$. cereus are considered unsafe for consumption [21].

With the aim to better evaluate the in vivo conditions of toxinogenesis, several studies assessed the cytotoxicity of $B$. cereus strains on $\mathrm{CHO}$, Vero, Hep-2 or Caco-2 cells [22-25]. In recent years, the accelerated emergence of foodborne pathogens resistant to a variety of antibiotics is one of the most serious threats for public health and clinical perspectives, which can cause perturbation in the empirical therapy during outbreaks. Many previous reports have shown that $B$. cereus group bacteria isolated from different foods are resistant to several antibiotics such as ampicillin, penicillin streptomycin, tetracycline, trimethoprim, and ceftriaxone [26-29]. Therefore, it is important to evaluate the resistance of foodborne $B$. cereus group bacteria to a variety of antibiotics for a better management of infectious diseases. The objective of the present work was to investigate the toxigenic potential of a collection of $174 \mathrm{~B}$. cereus group strains coming from Tunisian foodstuffs, (i) by detecting the presence of virulence genes, (ii) by assaying the cytotoxic activity of bacterial supernatants on Caco- 2 cells, and (iii) by assessing their antimicrobial resistance pattern towards selected antibiotics.

\section{Methods}

\section{Bacterial isolation and identification}

The collection analysed comprised 174 B. cereus group strains. They were previously isolated from 687 Tunisian food samples (cereals, spices, cooked food, canned products, seafood products, dairy products, fresh-cut vegetables, raw and cooked poultry meats), collected randomly from supermarkets, hotels, restaurants and private companies during the period from April 2014 to April 2015 [30]. Ten grams of each food sample were homogenized for $1 \mathrm{~min}$ with $90 \mathrm{ml}$ of buffered peptone water (VWR, Strasbourg, France) containing $5 \mathrm{~g} / \mathrm{l}$ of lithium chloride (Prolabo, Fontenay sur bois, France) in a BagMixer stomacher (AES Laboratory, Combourg, France). After serial dilution, $0.1 \mathrm{ml}$ of each diluted sample was streaked in Mannitol Egg Yolk Polymixin agar medium (MYP) (Oxoid, Basingstoke, England) and plates were incubated for $24 \mathrm{~h}$ at $30^{\circ} \mathrm{C}$. The presumptive identification of $B$. cereus group bacteria was based on the appearance of rough colonies with a violet-red background, and surrounded by a white egg yolk precipitate. One typical colony from each sample was subcultured and preserved as cryoculture at $-80^{\circ} \mathrm{C}$ after addition of glycerol (Sigma Aldrich, Saint Quentin Fallavier, France) at a final concentration of $25 \%$. To verify whether $B$. cereus-like isolates belonged to the $B$. cereus group, a PCR test targeting the sspE gene sequence specific of the group was carried out [31].

\section{DNA extraction}

Extraction of DNA was performed according to the Chelex extraction method [32]. Briefly, after twice overnight propagation of each frozen isolate in BHI-YE (Fisher Bioblock, Illkirch, France) at $30{ }^{\circ} \mathrm{C}$ without agitation, 5 $\mathrm{ml}$ of each culture was transferred into à $15 \mathrm{ml}$ falcon tube containing $300 \mu \mathrm{l}$ of $25 \%(\mathrm{~m} / \mathrm{v})$ sterile suspension of Chelex beads (Grosseron, Saint-Herblain, France) 
prepared in sterile Milli-Q water (Sigma Aldrich). Mixture was vortexed and centrifuged at $7000 \mathrm{rpm}$ for $7 \mathrm{~min}$ at $4{ }^{\circ} \mathrm{C}$. The cell pellet was resuspended in $200 \mu \mathrm{l}$ sterile Milli-Q water (Sigma Aldrich) and lysed by heating at $100{ }^{\circ} \mathrm{C}$ for $10 \mathrm{~min}$. After centrifugation at $7000 \mathrm{rpm}$ at $4{ }^{\circ} \mathrm{C}$ for $7 \mathrm{~min}, 150 \mu \mathrm{l}$ of supernatant was collected and re-centrifuged under the same conditions. The concentration of DNA was determined with a NanoDrop ND 1000 spectrophotometer (Nanodrop Technologies, Wilmington, USA) and the sample was diluted to a final concentration of approximately $100 \mathrm{ng} / \mu \mathrm{l}$.

\section{Detection of virulence genes}

Confirmed $B$. cereus group strains were screened for the emetic (ces) and the enterotoxigenic genes ( $h b l A, B, C$, and $D$, nheA, $B$, and $C, b c e T$ and $c y t K$ and its variants $c y t K-1$ and $c y t K-2)$ genes. All primers used as well as their annealing temperatures and the size of the amplified fragment for each gene are shown in Table 1. The detection of the ces cluster was tested with two different primer pairs [34, 35]. PCR amplification was systematically performed in a $28 \mu \mathrm{l}$ reaction volume. Each reaction mixture contained $5 \mu \mathrm{l}$ of $100 \mathrm{ng}$ DNA template, $2 \mu \mathrm{l}$ of each primer (Sigma Aldrich) with a concentration of $10 \mu \mathrm{M}, 0.3 \mu \mathrm{l}$ of Taq polymerase $(5000 \mathrm{U} / \mathrm{ml})$ (Biolabs, Evry, France), $0.5 \mu \mathrm{l}$ of $10 \mathrm{mM}$ deoxyribonucleotide triphosphate (Eurogentec, Seraing, Belgium), $1.12 \mu \mathrm{l}$ of $50 \mathrm{mM} \mathrm{MgCl} 2$ (Biolabs), $2.5 \mu \mathrm{l}$ of $10 \mathrm{X}$ AmpliTaq buffer (Biolabs) and $14.5 \mu \mathrm{l}$ of sterile Milli-Q water (Sigma Aldrich). The amplification reactions were carried out in a PCR thermocycler (iCycler optical module 584BR; BioRad, Marnes-la-Coquette, France). For the ces cluster, the amplification conditions were $5 \mathrm{~min}$ at $95^{\circ} \mathrm{C}$, followed by 30 cycles of $15 \mathrm{~s}$ at $95^{\circ} \mathrm{C}, 30 \mathrm{~s}$ at $58^{\circ} \mathrm{C}$ and $30 \mathrm{~s}$ at $72^{\circ} \mathrm{C}$ and a final extension at $72^{\circ} \mathrm{C}$ for $8 \mathrm{~min}$. For $h b l B$, the amplification conditions were $2 \mathrm{~min}$ at $94^{\circ} \mathrm{C}$ followed by 10 cycles of $10 \mathrm{~s}$ at $94{ }^{\circ} \mathrm{C}, 30 \mathrm{~s}$ at $58^{\circ} \mathrm{C}$, and 2 min at $68^{\circ} \mathrm{C}$. The ten cycles were followed by 20 cycles of $10 \mathrm{~s}$ at $94^{\circ} \mathrm{C}, 30 \mathrm{~s}$ at $58^{\circ} \mathrm{C}$, and $2 \mathrm{~min}$ (plus $20 \mathrm{~s}$ per cycle) at $68^{\circ} \mathrm{C}$; and a final extension at $68^{\circ} \mathrm{C}$ for $7 \mathrm{~min}$ [33]. For the remaining toxin genes $(h b l A, h b l C, h b l D$, nhe $A$, nheB, nheC, bceT and $c y t K$ and its variants $c y t K-1$ and $c y t K-2)$, the amplification conditions were $4 \mathrm{~min}$ at $95^{\circ} \mathrm{C}$ followed by 30 cycles of $30 \mathrm{~s}$ at $95^{\circ} \mathrm{C}, 30 \mathrm{~s}$ at the annealing temperatures (Table 1) and $1 \mathrm{~min}$ at $72^{\circ} \mathrm{C}$, and a final extension of $7 \mathrm{~min}$ at $72^{\circ} \mathrm{C}$. For each run, the whole PCR mix without any DNA template was used as a negative control. The positive controls for PCR amplification of virulence genes were the same as the ones used in Techer et al. study [36]. The mesophilic strain (TIAC 1095), harbouring the ces cluster, isolated from a Belgian emetic food poisoning event was used as positive

Table 1 Primers used in the simplex PCR for the detection of virulence genes in B. cereus

\begin{tabular}{|c|c|c|c|c|c|}
\hline Targeted Gene & Primer name & Sequence $\left(5^{\prime}-3^{\prime}\right)$ & Product Size (bp) & Annealing Temp $\left({ }^{\circ} \mathrm{C}\right)$ & Reference \\
\hline hblA & $\begin{array}{l}\text { HAF } \\
\text { HAR }\end{array}$ & $\begin{array}{l}\text { AAGCAATGGAATACAATGGG } \\
\text { AGAATCTAAATCATGCCACTGC }\end{array}$ & 1154 & 56 & [33] \\
\hline$h b / B$ & $\begin{array}{l}\text { HAF } \\
\text { HB R }\end{array}$ & $\begin{array}{l}\text { AAGCAATGGAATACAATGGG } \\
\text { AATATGTCCCAGTACACCCG }\end{array}$ & 2684 & 58 & [33] \\
\hline$h b / c$ & $\begin{array}{l}\text { HCF } \\
\text { HC R }\end{array}$ & $\begin{array}{l}\text { GATACTCAATGTGGCAACTGC } \\
\text { TTGAGACTGCTCGTCTAGTTG }\end{array}$ & 740 & 58 & [33] \\
\hline$h b / D$ & $\begin{array}{l}\mathrm{HDF} \\
\mathrm{HDR}\end{array}$ & ACCGGTAACACTATTCATGC GAGTCCATATGCTTAGATGC & 829 & 58 & [33] \\
\hline nheA & $\begin{array}{l}\text { NAF } \\
\text { NAR }\end{array}$ & $\begin{array}{l}\text { GTTAGGATCACAATCACCGC } \\
\text { ACGAATGTAATITGAGTCGC }\end{array}$ & 755 & 56 & [33] \\
\hline nheB & $\begin{array}{l}\text { NB F } \\
\text { NB R }\end{array}$ & $\begin{array}{l}\text { TTAAGTAGTGGATCTGTACGC } \\
\text { TTAATGTTCGTTAATCCTGC }\end{array}$ & 743 & 54 & [33] \\
\hline nhec & $\begin{array}{l}\text { NCF } \\
\text { NCR }\end{array}$ & TGGATTCCAAGATGTAACG ATTACGACTTCTGCTTGTGC & 683 & 54 & [33] \\
\hline bcet & $\begin{array}{l}\text { bceT-f } \\
\text { bceT-r }\end{array}$ & $\begin{array}{l}\text { GCTACGCAAAAACCGAGTGGTG } \\
\text { AATGCTCCGGACTATGCTGACG }\end{array}$ & 679 & 57 & [12] \\
\hline cytK & $\begin{array}{l}\text { CK F } \\
\text { CK R }\end{array}$ & $\begin{array}{l}\text { ACAGATATCGG(G,T)CAAAATGC } \\
\text { TCCAACCCAGTT(A,T)(G,C) CAGTTC }\end{array}$ & 809 & 54 & [11] \\
\hline cytK-1 & $\begin{array}{l}\text { CK1 F } \\
\text { CK1 R }\end{array}$ & $\begin{array}{l}\text { CAATTCCAGGGGCAAGTGTC } \\
\text { CCTCGTGCATCTGTTTCATGAG }\end{array}$ & 426 & 57 & [11] \\
\hline cytK-2 & $\begin{array}{l}\text { CK2 F } \\
\text { CK2 R }\end{array}$ & $\begin{array}{l}\text { CAATCCCTGGCGCTAGTGCA } \\
\text { GTGIAGCCTGGACGAAGTTGG }\end{array}$ & 585 & 57 & [11] \\
\hline \multirow[t]{2}{*}{ ces } & $\begin{array}{l}\text { EM1F } \\
\text { EM1R }\end{array}$ & $\begin{array}{l}\text { GACAAGAGAAATTTCTACGAGCAAGTAAT } \\
\text { GCAGCCTTCCAATTACTCCTTCTGCCACAGT }\end{array}$ & 635 & 58 & [34] \\
\hline & $\begin{array}{l}\text { CesF1 } \\
\text { CesR2 }\end{array}$ & $\begin{array}{l}\text { GGTGACACATTATCATATAAGGTG } \\
\text { GTAAGCGAACCTGTCTGTAACAACA }\end{array}$ & 1271 & 58 & [35] \\
\hline
\end{tabular}


control for PCR amplification of the emetic toxin gene. The strain C43, isolated from a food product [33], harbours hblA, hblB, hblC, hblD, nheA, nheB, nheC, and $c y t K$, and was used as positive control for PCR amplification of enterotoxigenic genes.

\section{Cytotoxic activity}

Cytotoxic activity of bacterial supernatants on Caco-2 cells were performed according to Jan et al. [24]. Briefly, after a defrosting step, Caco- 2 cells were cultivated on 96-well microplates at $37{ }^{\circ} \mathrm{C}$ under $5 \% \mathrm{CO}_{2}$ atmosphere for 3 to $4 \mathrm{~d}$ in Dulbecco modified Eagle medium (Sigma Aldrich) supplemented with $10 \%(\mathrm{v}$ : v) fetal calf serum (Cambrex, North Brunswick, N.J.), $100 \mathrm{UI} / \mathrm{ml}$ penicillin (Sigma Aldrich), $100 \mu \mathrm{g} / \mathrm{ml}$ streptomycin (Sigma Aldrich) and $2.5 \mu \mathrm{g} / \mathrm{ml}$ amphotericin B (Sigma Aldrich). Bacteria were grown for $18 \mathrm{~h}$ or $5 \mathrm{~d}$ at $30^{\circ} \mathrm{C}$ in BHI-YE, without agitation (Fisher Bioblock). After centrifugation $\left(10 \mathrm{~min}, 7000 \mathrm{rpm}, 4{ }^{\circ} \mathrm{C}\right.$ ), the supernatants were filtered through $0.2 \mu \mathrm{m}$ sterile filter units (Starstedt, Nümbrecht, Germany). After removal of the culture medium, Caco-2 cells were washed 3 times with phosphate buffered saline (PBS) (Gibco, Paisley, UK), incubated during $3 \mathrm{~h}$ with $50 \mu \mathrm{l}$ of each bacterial filtrate and then rinsed with PBS (Gibco) and fixed with $2 \%$ (w: v in PBS) paraformaldehyde (Sigma Aldrich) at $4{ }^{\circ} \mathrm{C}$ for $30 \mathrm{~min}$. After removal of the paraformaldehyde, the remaining cells were stained for $20 \mathrm{~min}$ at room temperature with $80 \mu$ lof crystal violet solution (Sigma Aldrich,). Cells were rinsed three times with distilled water, and the crystal violet solution was released from the cells by adding $200 \mu \mathrm{l}$ of $50 \%(\mathrm{v}: \mathrm{v})$ ethanol in water and shaking the microplates at room temperature for $45 \mathrm{~min}$. After transfer into new microplates, the amount of released dye was measured at $630 \mathrm{~nm}$ and was inversely related to the cytotoxic activity of culture filtrates. The cytotoxic activity was expressed as a percentage of inhibition compared with the control (BHI-YE alone), calculated as follows: (Optical Density (OD) control - OD assay)/OD control $\times$ 100. Filtrates were considered cytotoxic whenever the OD represented less than $50 \%$ of that of the control (percentage of inhibition higher than 50\%). Tests and controls were done in triplicate on the same microplate.

\section{Antibiotic susceptibility testing}

The antibiotic susceptibility of the isolates was studied using the Kirby-Bauer disk diffusion method [37]. Mueller-Hinton Agar (Merck, Darmstadt, Germany) was used for this test. All isolates were grown in BHI-YE (Fisher Bioblock) for $24 \mathrm{~h}$ at $30^{\circ} \mathrm{C}$, without agitation, followed by spreading on Mueller-Hinton agar plates. Eleven antimicrobials were chosen for antibiotic sensitivity testing, including ampicillin $(10 \mu \mathrm{g})$, vancomycin $(30 \mu \mathrm{g})$, gentamycin $(10 \mu \mathrm{g})$, erythromycin $(15 \mu \mathrm{g})$, tetracycline $(30 \mu \mathrm{g})$, ciprofloxacin $(5 \mu \mathrm{g})$, chloramphenicol $(30 \mu \mathrm{g})$, novobiocin $(30 \mu \mathrm{g})$, streptomycin $(10 \mu \mathrm{g})$, kanamycin $(30 \mu \mathrm{g})$ and rifampicin $(5 \mu \mathrm{g})$. All Muller-Hinton plates were incubated at $30^{\circ} \mathrm{C}$ for $18-24 \mathrm{~h}$. The inhibition zones were measured and interpreted referring to the Clinical and Laboratory Standards Institute (CLSI) [38], which contains measurement ranges and their equivalent qualitative categories of susceptible, intermediately susceptible or resistant.

\section{Statistical analyses}

The statistical analyses, including $t$-tests, and ANOVA $F$-test, were performed using the $\mathrm{R}$ - 3.4.2. statistic software. A $p$-value $<0.05$ was considered as statistically significant for all the parameters evaluated. The $F$-test was used to assess the potential relationship between (i) the origin of the strains and their cytotoxity and (ii) the type of virulence factors they harbour and their level of cytotoxity. The $t$-tests were used to assess the level of cytotoxicity of each strain inside the collection as well as the potential correlation between the type of virulence factors they harbour and their level of cytotoxicity.

\section{Results \\ Distribution of enterotoxin and emetic toxin-encoding genes among $B$. cereus collection}

In order to characterize the virulence potential of foodborne $B$. cereus group bacteria in Tunisia, 174 isolates from different kinds of foods were screened by PCR for the presence of nine diarrhoeal toxin-encoding genes (hblABCD complex, nheABC complex, bceT, and cytK and its variants) and one emetic toxin-encoding gene (ces). At least one gene of each NHE and HBL complexes was detected in 100 and $59.2 \%$ of strains, respectively. The enterotoxin genes detected among $B$. cereus isolates were, in decreasing order, nheA (98.9\%), nheC (97.7\%) and nheB (86.8\%) versus $h b l C$ (54.6\%), hblD (54.6\%), hblA (29.9\%) and $h b l B(14.9 \%)$, respectively for the NHE and HBL complexes.

The genetic determinants of the NHE complex were shown to be the most common genes detected inside the collection. All three genes of the NHE complex were detected in $84.5 \%(147 / 174)$ of the collection. The presence of two genes was observed in $14.4 \%$ (25/174) of the collection, while $1.1 \%(2 / 174)$ of the collection harboured only one gene (Table 2). The four genes encoding the HBL complex were detected in $13.8 \%$ (24/174) of the collection, three genes were present in $22.4 \%$ (39/ $174)$ of the collection; $14.4 \%(25 / 174)$ were positive for two genes, $8.6 \%(15 / 174)$ had a single gene of the complex, while $40.8 \%$ (71/174) had no HBL genes (Table 2). The $c y t K$ gene was present in $37.9 \%$ of the strains but further testing revealed that strains harbouring the $c y t K$ gene 
Table 2 Total distribution of virulence genes in B. cereus strains collection ( $n=174)$ isolated from foodstuffs in Tunisia

\begin{tabular}{|c|c|c|c|c|c|c|c|c|c|c|c|}
\hline \multirow{2}{*}{$\begin{array}{l}\text { Toxigenic } \\
\text { genes }\end{array}$} & \multicolumn{11}{|c|}{ No. (\%) of strains positive for target gene(s) } \\
\hline & $\begin{array}{l}\text { Cooked } \\
\text { food } \\
(n=42)\end{array}$ & $\begin{array}{l}\text { Pastry } \\
\text { products } \\
(n=37)\end{array}$ & $\begin{array}{l}\text { Cereal } \\
\text { products } \\
(n=23)\end{array}$ & $\begin{array}{l}\text { Cooked } \\
\text { poultry meat } \\
(n=18)\end{array}$ & $\begin{array}{l}\text { Spices } \\
(n=17)\end{array}$ & $\begin{array}{l}\text { Seafood } \\
\text { products } \\
(n=11)\end{array}$ & $\begin{array}{l}\text { Canned } \\
\text { products } \\
(n=9)\end{array}$ & $\begin{array}{l}\text { Raw poultry } \\
\text { meat } \\
(n=8)\end{array}$ & $\begin{array}{l}\text { Fresh-cut } \\
\text { vegetables } \\
(n=5)\end{array}$ & $\begin{array}{l}\text { Dairy } \\
\text { products } \\
(n=4)\end{array}$ & $\begin{array}{l}\text { Total } \\
(\mathrm{n}=174)\end{array}$ \\
\hline \multicolumn{12}{|c|}{ HBL gene complexes } \\
\hline$h b / c$ & $1(2.4)$ & $4(10.8)$ & $1(4.3)$ & $1(5.6)$ & $0(0.0)$ & $0(0.0)$ & $0(0.0)$ & $0(0.0)$ & $0(0.0)$ & $0(0.0)$ & $7(4.0)$ \\
\hline$h b / D$ & $3(7.1)$ & $0(0.0)$ & $1(4.3)$ & $0(0.0)$ & $1(5.9)$ & $1(9.1)$ & $0(0.0)$ & $2(25.0)$ & $0(0.0)$ & $0(0.0)$ & $8(4.6)$ \\
\hline $\begin{array}{l}\text { hblat } \\
\text { hblc }\end{array}$ & $1(2.4)$ & $0(0.0)$ & $0(0.0)$ & $0(0.0)$ & $0(0.0)$ & $0(0.0)$ & $0(0.0)$ & $0(0.0)$ & $0(0.0)$ & $0(0.0)$ & $1(0.6)$ \\
\hline $\begin{array}{l}h b / c+ \\
h b l D\end{array}$ & $7(16.7)$ & $8(21.6)$ & $2(8.7)$ & $0(0.0)$ & $0(0.0)$ & $1(9.1)$ & $2(22.2)$ & $0(0.0)$ & $3(60.0)$ & $1(25.0)$ & $24(13.8)$ \\
\hline $\begin{array}{l}h b l A+ \\
h b / C+ \\
h b l D\end{array}$ & $5(11.9)$ & $4(10.8)$ & $2(8.7)$ & $3(16.7)$ & $7(41.2)$ & $4(36.4)$ & $0(0.0)$ & $1(12.5)$ & $1(20.0)$ & $0(0.0)$ & $27(15.5)$ \\
\hline $\begin{array}{l}h b l B+ \\
h b l C+ \\
h b l D\end{array}$ & $2(4.8)$ & $3(8.1)$ & $1(4.3)$ & $2(11.1)$ & $1(5.9)$ & $1(9.1)$ & $1(11.1)$ & $1(12.5)$ & $0(0.0)$ & $0(0.0)$ & $12(6.9)$ \\
\hline $\begin{array}{l}\text { hblA+ } \\
\text { hblB+ } \\
\text { hblc+ } \\
\text { hblD }\end{array}$ & $6(14.3)$ & $8(21.6)$ & $5(21.8)$ & $2(11.1)$ & $3(17.6)$ & $0(0.0)$ & $0(0.0)$ & $0(0.0)$ & $0(0.0)$ & $0(0.0)$ & $24(13.8)$ \\
\hline $\begin{array}{l}\text { None } \\
\text { detected }\end{array}$ & $17(40.4)$ & $10(27.0)$ & $11(47.8)$ & $10(55.6)$ & $5(29.4)$ & $4(36.4)$ & $6(66.7)$ & $4(50.0)$ & $1(20.0)$ & $3(75.0)$ & $71(40.8)$ \\
\hline \multicolumn{12}{|c|}{ NHE gene complexes } \\
\hline nheA & $1(2.4)$ & $0(0.0)$ & $0(0.0)$ & $0(0.0)$ & $0(0.0)$ & $0(0.0)$ & $0(0.0)$ & $0(0.0)$ & $0(0.0)$ & $0(0.0)$ & $1(0.6)$ \\
\hline nheB & $0(0.0)$ & $0(0.0)$ & $0(0.0)$ & $0(0.0)$ & $1(5.9)$ & $0(0.0)$ & $0(0.0)$ & $0(0.0)$ & $0(0.0)$ & $0(0.0)$ & $1(0.6)$ \\
\hline $\begin{array}{l}\text { nheAt } \\
\text { nheB }\end{array}$ & $9(21.4)$ & $4(10.8)$ & $1(4.3)$ & $1(5.6)$ & $1(5.9)$ & $2(18.2)$ & $0(0.0)$ & $3(37.5)$ & $0(0.0)$ & $1(25.0)$ & $22(12.6)$ \\
\hline $\begin{array}{l}\text { NheAt } \\
\text { nhec }\end{array}$ & $2(4.8)$ & $0(0.0)$ & $0(0.0)$ & $0(0.0)$ & $0(0.0)$ & $0(0.0)$ & $0(0.0)$ & $0(0.0)$ & $0(0.0)$ & $0(0.0)$ & $2(1.1)$ \\
\hline $\begin{array}{l}\text { nheB+ } \\
\text { nhec }\end{array}$ & $1(2.4)$ & $0(0.0)$ & $0(0.0)$ & $0(0.0)$ & $0(0.0)$ & $0(0.0)$ & $0(0.0)$ & $0(0.0)$ & $0(0.0)$ & $0(0.0)$ & $1(0.6)$ \\
\hline $\begin{array}{l}\text { nheA+ } \\
\text { nheB+ } \\
\text { nheC }\end{array}$ & $29(69.0)$ & 33 (89.2) & $22(95.7)$ & $17(94.4)$ & $\begin{array}{l}15 \\
(88.2)\end{array}$ & $9(81.8)$ & $9(100.0)$ & $5(62.5)$ & $5(100.0)$ & $3(75.0)$ & $\begin{array}{l}147 \\
(84.5)\end{array}$ \\
\hline $\begin{array}{l}\text { None } \\
\text { detected }\end{array}$ & $0(0.0)$ & $0(0.0)$ & $0(0.0)$ & $0(0.0)$ & $0(0.0)$ & $0(0.0)$ & $0(0.0)$ & $0(0.0)$ & $0(0.0)$ & $0(0.0)$ & $0(0.0)$ \\
\hline \multicolumn{12}{|l|}{ Other genes } \\
\hline cytk & $13(30.1)$ & $15(40.54)$ & $9(39.1)$ & $6(33.3)$ & $9(52.9)$ & $8(72.7)$ & $3(33.3)$ & $1(12.5)$ & $1(20.0)$ & $1(25.0)$ & $66(37.9)$ \\
\hline bcet & $17(40.4)$ & $20(54.1)$ & $14(60.9)$ & $9(50.0)$ & $\begin{array}{l}10 \\
(58.8)\end{array}$ & $10(90.9)$ & $2(22.2)$ & $5(62.5)$ & $1(20.0)$ & $0(0.0)$ & $88(50.6)$ \\
\hline ces & $2(4.8)$ & $1(2.7)$ & $0(0.0)$ & $3(16.7)$ & $1(5.9)$ & $0(0.0)$ & $0(0.0)$ & $0(0.0)$ & $0(0.0)$ & $0(0.0)$ & $7(4.0)$ \\
\hline
\end{tabular}

belonged to the $c y t K-2$ type. None of the B. cereus strains haboured the $c y t K-1$ variant.

The $b c e T$ and ces genes were present in 50.6 and $4 \%$ of the collection, respectively (Table 2).

The virulence genes were widely distributed regardless the origin of the strains, except for the emetic toxin-encoding gene (ces) that was only detected in the strains coming from cooked poultry meat, cooked food, pastry products and spices. All isolates presented at least one of the genes investigated. The virulence genes distribution revealed a toxigenic diversity among $B$. cereus group isolates (Table 3). Twelve groups (G1 to G12) are compiled in Table 3.

Cytotoxic activity of $B$. cereus strains on Caco-2 cells

Each of the 174 isolates was able to grow in BHI-YE. The average bacterial population was $8 \pm 0.3$ and $7 \pm 0.5$ $\log _{10} \mathrm{CFU} / \mathrm{ml}$ after $18 \mathrm{~h}$ and $5 \mathrm{~d}$ incubation at $30^{\circ} \mathrm{C}$, respectively (results not shown). The percentage of cytotoxic strains observed after $18 \mathrm{~h}$ incubation (70.7\%) was twice the one observed after $5 \mathrm{~d}$ incubation (35\%) in BHI-YE at $30{ }^{\circ} \mathrm{C}$ (results not shown). 
Table 3 Distribution of different combinations of virulence genes in B. cereus group isolates in different groups

\begin{tabular}{llll}
\hline Group & Genes presents & Number of isolates & \% isolates in each group \\
\hline G1 & HBL complex, NHE complex, bceT, cytK & $36\left(8+26^{\mathrm{a}}+1^{\mathrm{b}}+1^{\mathrm{c}}\right)$ & 20.7 \\
G2 & HBL complex, NHE complex, bceT & $29\left(9+15^{\mathrm{a}}+1^{\mathrm{b}}+4^{\mathrm{c}}\right)$ & 16.7 \\
G3 & HBL complex, NHE complex, cytK & $7\left(1+3^{\mathrm{a}}+3^{\mathrm{c}}\right)$ & 4.0 \\
G4 & HBL complex, NHE complex & $30\left(4+16^{\mathrm{a}}+10^{\mathrm{c}}\right)$ & 17.2 \\
G5 & NHE complex, bceT, cytK & 8 & 4.6 \\
G6 & NHE complex, bceT & $13\left(10+3^{\mathrm{b}}\right)$ & 7.5 \\
G7 & NHE complex, cytK & $12\left(11+1^{\mathrm{b}}\right)$ & 6.9 \\
G8 & NHE complex & $32\left(30+2^{\mathrm{b}}\right)$ & 18.4 \\
G9 & NHE complex, HBL complex, ces & $1^{\mathrm{c}}$ & 0.6 \\
G10 & NHE complex, cytK, ces & 3 & 1.7 \\
G11 & NHE complex, bceT, ces & 2 & 1.1 \\
G12 & NHE complex, ces & 1 & 0.6 \\
\hline
\end{tabular}

aLacked at least one gene of HBL complex; ${ }^{\text {b }}$ Lacked at least one gene of NHE complex; ${ }^{\circ}$ Lacked at least one gene of NHE \& HBL complex

\section{Cytotoxicity and strains origins}

A significant correlation is found regarding the cytotoxicity and the source of strains $(F$ - test, $p<0.05)$. As compared to strains isolated from spices, a significant dispersion of cytotoxic activity has been reported for strains isolated from fresh cut vegetables, cereals or dairy products $(p<0.05)$. Cytotoxic activity was comparable in all strains when isolated from cooked and raw poultry meat, canned products, pastry products and cooked foods $(p>0.05)$. For strains isolated from seafood and spices, the level of cytotoxicity was significantly influenced by the incubation time of the bacterial culture $(p=0.0004)$. After $18 \mathrm{~h}$ of incubation, a significant difference in cytotoxic activity was observed. However, after 5 days of incubation, cytotoxicity was found to be comparable $(p>0.05, p=0.09)$ (results not shown).

\section{Cytotoxicity and virulence gene profiles}

The involvement of several known virulence factors in the cytotoxicity on Caco-2 cells was evaluated. The presence of the HBL genetic determinants was not related to the cytotoxicity. Indeed, among strains possessing or not possessing the four genetic determinants of the $\mathrm{HBL}$ complex, cytotoxic and non-cytotoxic strains were found. The percentage of cytotoxic strains harbouring the four genes was higher after $18 \mathrm{~h}$ than after $5 \mathrm{~d}$ incubation. Therefore, among the 24 strains possessing the whole HBL genetic determinants, 79.2 and $41.7 \%$ displayed toxicity on Caco-2 cells after $18 \mathrm{~h}$ and $5 \mathrm{~d}$ incubation, respectively. Although 147 strains carried the three genetic determinants of the NHE complex, only 68.7 and $36.7 \%$ of them were shown to be cytotoxic after $18 \mathrm{~h}$ and $5 \mathrm{~d}$ incubation, respectively. Moreover, among the strains that lacked one or two of the genetic determinants of the NHE complex, both cytotoxic and non- cytotoxic strains were highlighted at both time of incubation.

Several combinations of NHE and HBL genetic determinants were significantly associated ( $t$-test, $p<0.05)$ with the cytotoxic activity of culture supernatants (Table 4). The level of cytotoxicity increased significantly $(+12 \%$ and $+14 \%$ after $18 \mathrm{~h}$ and $5 \mathrm{~d}$ incubation, respectively) when strains harbored simultaneously $h b l C$ and $n h e C$. The presence of $h b l C$ and $n h e B$ had a significant positive incidence on the cytotoxicity $(+27 \%$ and $+23 \%$ after $18 \mathrm{~h}$ and $5 \mathrm{~d}$, respectively). However, the presence of $n h e B$ and the absence of $h b l C$ was associated with a decrease of the cytotoxicity after $5 \mathrm{~d}$ incubation (-17\%). The simultaneous presence of $h b l B$ and $n h e A$ significantly correlated with the cytotoxic activity after $5 \mathrm{~d}$ incubation (+11\%). The cytotoxity of supernatent after 5 d incubation decrease by $29 \%$ when strains harbored $h b l B$ but not nheA. The simultaneous carriage of $h b l D$ and $n h e C$ was inversely associated with cytotoxicity. It decreased by $8 \%$ and $-14 \%$ after $18 \mathrm{~h}$ and $5 \mathrm{~d}$ incubation, respectively.

Among the isolates that possess the $c y t K$ gene, there were both cytotoxic and non-cytotoxic strains after $18 \mathrm{~h}$ and $5 \mathrm{~d}$ incubation. As shown in Table 4, a significant correlation was shown between cytotoxicity and the combination of cytK: $h b l D$ as well as with the combination of $c y t K: h b l B$ with the absence of $n h e C$, after $18 \mathrm{~h}$ incubation. Both cytK: nheC and cytK: hblC combinations were inversely correlated with the cytotoxic activity after $18 \mathrm{~h}$ incubation.

$b c e T$ was present in cytotoxic strains as well as in safe strains. The simultaneous presence of $b c e T$, nheC and $h b l B$ was significantly associated with a lower cytotoxic activity after $18 \mathrm{~h}(-17 \%)$ (Table 4). However, when bce $T$ was present with $n h e C$ or $h b l D$, the cytotoxicity after $18 \mathrm{~h}$ incubation decreased by 12 and $6 \%$, 
Table 4 Statistical analyses of associations between the presence or absence of virulence factors and cytotoxicity on Caco-2 cells

\begin{tabular}{|c|c|c|c|c|c|c|c|c|c|}
\hline \multicolumn{5}{|l|}{$F$-test } & \multicolumn{5}{|l|}{$\underline{t \text {-test }}$} \\
\hline \multirow{3}{*}{$\begin{array}{l}\text { Significant } \\
\text { association } \\
\text { tested } \\
\text { Cytotoxicity } \\
\text { versus } \\
\text { virulence } \\
\text { factors }\end{array}$} & \multicolumn{2}{|l|}{ Sum Sq } & \multicolumn{2}{|l|}{$p$-value } & \multirow{3}{*}{$\begin{array}{l}\text { Significant } \\
\text { association } \\
\text { tested } \\
\text { Cytotoxicity }_{\text {versus }} \\
\text { Presence }^{\mathrm{b}} / \\
\text { Absence }^{\mathrm{a}} \text { of } \\
\text { virulence factors }^{\text {virle }}\end{array}$} & \multirow{2}{*}{\multicolumn{2}{|c|}{$\frac{\text { Estimate }}{\text { Cytotoxicity after }}$}} & \multirow{2}{*}{\multicolumn{2}{|c|}{$\frac{p \text {-value }}{\text { Cytotoxicity after }}$}} \\
\hline & \multicolumn{2}{|c|}{ Cytotoxicity after } & \multicolumn{2}{|c|}{ Cytotoxicity after } & & & & & \\
\hline & $18 \mathrm{~h}$ & $5 d$ & $18 \mathrm{~h}$ & $5 d$ & & $18 \mathrm{~h}$ & $5 d$ & $18 \mathrm{~h}$ & $5 d$ \\
\hline \multirow[t]{2}{*}{ hblc:hblD } & 5562 & 20,994 & $0.0032 * *$ & $4.57 \mathrm{E}-08 * * *$ & $h b / C^{b}: h b l D^{b}$ & ND & 14 & ND & $4.75 \mathrm{E}-08$ *** \\
\hline & & & & & $h b / c^{a}: h b l D^{b}$ & -10 & ND & 0.0034 * & ND \\
\hline \multirow[t]{2}{*}{ hblc:nheB } & 13,568 & 10,441 & $1.58 \mathrm{E}-07 * * *$ & $0.0005 * *$ & $h b / c^{b}: n h e B^{b}$ & 27 & 24 & $1.58 \mathrm{E}-07 * * *$ & $0.0073 * *$ \\
\hline & & & & & $h b / c^{a}: n h e B^{b}$ & ND & -17 & ND & $0.0058 * *$ \\
\hline hblc:nhec & 6497 & 11,695 & $0.0002 * * *$ & $4.08 \mathrm{E}-05 * * *$ & $h b / d^{b}:$ nhe $^{b}$ & 12 & 14 & $0.0003 * * *$ & $4.08 \mathrm{E}-05^{* * *}$ \\
\hline hblD:nhec & 3675 & 11,106 & $0.0058 * *$ & $6.33 \mathrm{E}-05 * * *$ & $h b l D^{b}:$ nhe ${ }^{b}$ & -8 & -14 & $0.0058 * *$ & $6.33 \mathrm{E}-05^{* * *}$ \\
\hline \multirow[t]{2}{*}{ bcet: hblB } & 23,036 & 8048 & $1.12 \mathrm{E}-10 * * *$ & $0.0006 * *$ & $b c e T^{b}: h b l B^{b}$ & 18 & 10 & $0.0002 * *$ & $0.0006^{* * *}$ \\
\hline & & & & & $b c e T^{a}: h b / B^{b}$ & -16 & ND & $3.07 \mathrm{E}-07 * * *$ & ND \\
\hline \multirow[t]{3}{*}{ nhec:bceT:hblB } & 11,787 & 6560 & $6.14 \mathrm{E}-06 * * *$ & $0.0085^{* *}$ & $n h e c^{b}: b c e T^{b}: h b l B^{b}$ & -17 & ND & $0.0004^{* * *}$ & ND \\
\hline & & & & & nhe $C^{b}: b c e T^{a}: h b l B^{b}$ & 9 & ND & $0.004 * *$ & ND \\
\hline & & & & & nhe $C^{b}:$ bcet $T^{b}: h b l B^{a}$ & ND & 6 & ND & $0.012 *$ \\
\hline bceT:hblD & 11,867 & ND & $8.99 \mathrm{E}-07 * * *$ & ND & bcetb:hblD ${ }^{b}$ & -6 & ND & $8.99 \mathrm{E}-07^{* * *}$ & ND \\
\hline bceT:nhec & 4733 & ND & $0.0017 * *$ & ND & bcet $T^{b}$ :nhe ${ }^{b}$ & -12 & ND & $0.0017 * *$ & ND \\
\hline ces:hb/c & 9828 & ND & $7.46 \mathrm{E}-06 * * *$ & ND & ces $^{b}: h b / c^{b}$ & -17 & ND & $7.46 \mathrm{E}-06^{* * *}$ & ND \\
\hline cytK:hblD & 19,045 & ND & $6.51 \mathrm{E}-10 * * *$ & ND & $c y t K^{b}: h b l D^{b}$ & 14 & ND & $6.51 \mathrm{E}-10 * * *$ & ND \\
\hline cytK:nheC & 6617 & ND & $0.0002 * * *$ & ND & $c y t K^{b}: n h e C^{b}$ & -12 & ND & $0.0002 * * *$ & ND \\
\hline cytK:nheC:hblB & 4501 & ND & 0.0095 ** & ND & $c y t K^{b}: n h e c^{a}: h b l B^{b}$ & 12 & ND & $0.011 *$ & ND \\
\hline hblc:cytk & 15,874 & ND & $1.53 \mathrm{E}-08 * * *$ & ND & $h b / C^{b}: c y t K^{b}$ & -12 & ND & $1.53 \mathrm{E}-08^{* * *}$ & ND \\
\hline$h b / D: h b / A$ & 2417 & ND & $0.025 *$ & ND & $h b l D^{b}: h b l A^{b}$ & -8 & ND & $0.025 *$ & ND \\
\hline \multirow[t]{2}{*}{ nheB:nhec } & 6500 & ND & $0.0012^{* *}$ & ND & nhe $B^{a}$ :nhe ${ }^{b}$ & 27 & ND & $0.01 *$ & ND \\
\hline & & & & & $n h e B^{b}:$ nhe $C^{b}$ & -9 & ND & $0.018 *$ & ND \\
\hline bceT:hblA & ND & 8530 & ND & $0.002 * *$ & $b c e T^{b}: h b / A^{b}$ & ND & -7 & ND & $0.0008^{* * *}$ \\
\hline$h b / c: h b / B$ & ND & 5000 & ND & $0.007 * *$ & $h b / C^{b}: h b l B^{b}$ & ND & -11 & ND & $0.007 * *$ \\
\hline \multirow[t]{2}{*}{ nheA:hblB } & ND & 8433 & ND & $0.002 * *$ & $n h e A^{a}: h b / B^{b}$ & ND & -29 & ND & $0.047 *$ \\
\hline & & & & & $n h e A^{b}: h b / B^{b}$ & ND & 11 & ND & $0.025 *$ \\
\hline \multirow[t]{2}{*}{ cytK:hbla } & 3400 & ND & $0.029 *$ & ND & $c y t K^{b}: h b l A^{b}$ & NS & ND & $>0.05$ & ND \\
\hline & & & & & $c y t K^{a}: h b l A^{b}$ & NS & ND & $>0.05$ & ND \\
\hline \multirow[t]{2}{*}{ cytK:nheC:hblA } & 3165 & ND & 0.0375 * & ND & $c y t K^{b}: n h e C^{b}: h b / A^{b}$ & NS & ND & $>0.05$ & ND \\
\hline & & & & & $c y t K^{a}: n h e C^{b}: h b l A^{b}$ & NS & ND & $>0.05$ & ND \\
\hline
\end{tabular}

absence; ${ }^{b}$ presence; ND Not determined; NS Not significant ( $p$-value $\left.\geq 0.05\right) ;{ }^{*}:$ significant ( $p$-value: 0.01 to 0.05$)$; **: very significant ( $p$-value: 0.001 to 0.01$) ; * * *:$ very significant ( $p$-value $<0.001)$

respectively. After $18 \mathrm{~h}$ incubation, the cytotoxicity increased significantly $(18 \%)$ when strains harbored $b c e T$ and $h b l B$. When strains carried $h b l B$ but lacked $b c e T$, the cytotoxicity decreased significantly by $16 \%$ (Table 4 ). The absence of $b c e T$ was associated with a higher cytotoxic activity after $18 \mathrm{~h}(+9 \%)$ when strains harbored simultaneously $n h e C$ and $h b l B$, whereas it was lower ($17 \%)$ when strains harbored simultaneously $n h e C, h b l B$ and $n h e C$ and $h b l B$.
After $5 \mathrm{~d}$, the cytotoxicity was higher when strains possessed simultaneously $b c e T$ and $h b l B(+10 \%)$ and when carried $b c e T$ and nheC but not $h b l B(+6 \%)$ (Table 4). However, the cytotoxicity was lower when strains harbored simultaneously bceT and hblA ($7 \%)$.

All the strains harbouring the ces gene have cytotoxic activity against Caco- 2 cells after $18 \mathrm{~h}$ incubation. When ces was associated with $h b l C$, the cytotoxicity was 
significantly lower (-17\%) (Table 4). Moreover, no cytotoxic activity was found for these strains after $5 \mathrm{~d}$ incubation.

\section{Antibiotic susceptibility}

The susceptibility of 174 B. cereus isolates was tested for 11 different antibiotics. The results of the antimicrobial tests are presented in Table 5. All B. cereus strains were fully sensitive to rifampicin, chloramphenicol, ciprofloxacin, and gentamycin. The majority of the isolates were susceptible to streptomycin (98.9\%), kanamycin (96.6\%), erythromycin (95.4\%), vancomycin (92\%) and tetracycline $(85.1 \%)$. In addition, all isolates were resistant to ampicillin (90.8\%) and novobiocin (88\%).

\section{Discussion}

This study revealed the toxigenic potential of $B$. cereus group strains collection isolated from different kinds of foodstuffs collected in Tunisia. The pathogenic abilities of $B$. cereus group strains were evaluated by examination of the presence of virulence factors, the cytotoxic activity and the antimicrobial resistance.

The isolates are multi-toxigenic, harbouring at least one gene of each NHE and HBL complexes associated or not to bceT, cytK-2 and ces genes. The inability to detect all genes by PCR in most isolates is due to the existence of a polymorphism in the sequences of HBL and NHE complexes genes rather than their absence [33]. According to our results, the genes of the HBL complex were less common than that of the NHE complex. The low prevalence of genetic determinants of the HBL complex compared to those of the NHE complex has been demonstrated in previous studies [22, 39-41]. The incidence of $n h e$ and $h b l$ was within the ranges described by Ceuppens et al. [15]. They reported that 84 to $100 \%$ of

Table 5 Antibiotic susceptibility of 174 B. cereus strains isolated from foodstuffs in Tunisia

\begin{tabular}{lllll}
\hline Antibiotics & $\begin{array}{l}\text { Conc. } \\
(\mu \mathrm{g} / \\
\text { disc })\end{array}$ & Rosistant & Intermediate & Susceptible \\
\cline { 4 - 5 } & 5 & 0 & 0 & $174(100)$ \\
\hline Rifampicin & 15 & $2(1.2)$ & $6(3.4)$ & $166(95.4)$ \\
Erythromycin & 30 & 0 & 0 & $174(100)$ \\
Chloramphenicol & 30 & $153(88)$ & $13(7.5)$ & $8(4.5)$ \\
Novobiocin & 10 & $158(90.8)$ & $11(6.3)$ & $5(2.9)$ \\
Ampicillin & 5 & 0 & 0 & $174(100)$ \\
Ciprofloxacin & 10 & $2(1.1)$ & 0 & $172(98.9)$ \\
Streptomycin & 10 & 0 & 0 & $174(100)$ \\
Gentamycin & 30 & $7(4)$ & $7(4)$ & $160(92)$ \\
Vancomycin & 30 & 0 & $6(3.4)$ & $168(96.6)$ \\
Kanamycin & 30 & $10(5.7)$ & $16(9.2)$ & $148(85.1)$ \\
Tetracycline & & &
\end{tabular}

B. cereus group strains possessed nhe while $h b l$ was detected in 29 to $92 \%$ of the isolates they studied. All (100\%) the B. cereus group strains harbored at least one gene of the NHE complex. One hundred and three isolates (59.2\%) carried at least one of the HBL genetic determinants. Similarly, Tewari et al. [39] reported that 55.2 and $89.7 \%$ of the B. cereus strains they studied were positive for at least one of the HBL and NHE genetic determinants, respectively. These results are in contrast to those of Ngamwongsatit et al. [42] who reported that none of the $411 \mathrm{~B}$. cereus group strains they studied showed the presence of only a single or two genes in either the HBL or NHE complexes. cytK was detected in $37.9 \%$ of the collection. A similar occurrence was observed for strains isolated from cooked chilled food and vegetables [33], meat products [39] and cereal products "sunsik" [43]. However, the occurrence reaches up to $77 \%$ for strains isolated from cereal products, "sunsik" [44], and ready to eat meals, spices, dairy products, starches and flours [45]. The percentage of strains carrying bceT (50.6\%) was in agreement with the results of Bonerba et al. [46], who demonstrated that $52 \%$ of the isolates coming from pastries, rice samples, potato meals, mozzarella and meat meals possessed this gene. According to Guinebretière, et al. [33], bceT appears as widely distributed in food-borne strains isolated from cooked chilled food and vegetables (71\%), whereas a low occurrence of this gene was highlighted by Yang et al. [47] in food-related B. cereus group isolates (11.8\%). As stated above, the occurrence of enterotoxin genes varies greatly depending on the study. This variability may be ascribed to various geographical locations, various sources of strains and the use of various primers for PCR assays.

Among all the strains tested in this study, only seven strains (4\%) harboured the ces gene. These strains were detected in cooked poultry products, pastry products, cooked food and spices. The emetic intoxication is frequently associated with starchy foods such as rice, noodles, pasta and mashed potato [3, 48, 49]. Furthermore, similarly to our findings, López et al. [50] and Messelhäusser et al. [51] reported that emetic B. cereus group strains were detected in cooked chicken and foods such as soups, sauces, and mixed or buffet meals. However, none of the B. cereus group strains isolated from spices possessed the emetic toxin gene (ces) in the studies of Hariram and Labbé [52] and of Fogele et al. [53]. Therefore, the prevalence of emetic B. cereus group bacteria in different types of foods need to be further investigated in order to decipher the potential contamination sources.

Based on the incidence of all the virulence genes ( $h b l A B C D$, nhe $A B C, c y t K, b c e T$ and ces), B. cereus group strains were divided into 12 different groups (Table 3 ). 
This finding indicates that the $B$. cereus group is likely diverse in food. The detection at least of one gene from the HBL and/or NHE complex indicates the presence of both nhe and hbl operons [54]. The polymorphism among HBL and NHE complexes is the likely explanation of the failure to identify all genes in most $B$. cereus isolates by PCR [33]. Therfore, when strains carried at least one toxin gene, this later could be a target marker for screening toxigenic $B$. cereus group strains in food.

Emetic B. cereus group strains were heterologous at a genotypic level. They belonged to different toxigenic groups (G9- G12). The emetic B. cereus group strain belonging to the G12 group carried NHE complex genes and not those of the HBL complex. The virulence profile of these strains is consistent with the studies of EhlingSchulz et al. [35], Lee et al. [43] and Yang et al. [55], where an absence of correlation was observed between the presence of the ces gene and of the HBL complex that is common in non-emetic strains.

Noteworthy, the strains belonging to the G9 group possessed the ces gene together with incomplete NHE and HBL complexes. Our finding is in agreement with previous studies that detected emetic strains positive for both ces and HBL complex genes [56, 57].

In addition to the NHE complex and the ces genes, the emetic strains belonging to the G10 and G11 groups possessed $c y t K$ and $b c e T$, respectively. Similarly, previous studies $[55,58]$ reported that emetic strains harboured $c y t K$ or $b c e T$. Thus, emetic B. cereus group strains containing various enterotoxin genes such as those of the NHE and HBL complexes, cytK and/or $b c e T$ could have the potential to cause diarrheal and emetic food poisoning simultaneously.

The majority of the B. cereus strains of the collection (70.7\%) was cytotoxic after $18 \mathrm{~h}$ of incubation at $30^{\circ} \mathrm{C}$. However, the cytotoxicity decreased after $5 \mathrm{~d}$ incubation. Only $35 \%$ of strains were found cytotoxic at this time of culture. The fact that the percentage of cytotoxic strains was lower after $5 \mathrm{~d}$ of incubation than after $18 \mathrm{~h}$ was probably the result of dying of cells [24] and/or toxin degradation [59]. In our collection, the percentage of cytotoxic strains was higher than those reported by Choma et al. [23]; Jan et al. [24]; Stenfors et al. [25] and Techer et al. [36]. However, the comparison with the results obtained by other authors is difficult because there is a wide diversity in the methods used to test cytotoxicity (various cellular types, incubation times and temperatures, etc.) and the variety of tested foods (milk, vegetables or laboratory collections).

Based on various cellular assays, cytotoxic activity of CytK, NHE and HBL was proven in vitro in previous studies [18, 60-63]. Enterotoxin $\mathrm{T}$ showed no cytotoxicity and could probably not contribute to food poisoning [13].
Several studies reported that none of the virulence factor was able individually or in combination to fully explain the cytotoxic potential of B. cereus group bacteria [22, 61, 64, 65]. In contrast, our study confirmed that different combinations of enterotoxin genetic determinants are significantly associated to the cytotoxic potential of the bacteria. Therefore, the combined and possibly synergistic action of multiple toxins can probably explain the diarrheal syndrome related to B. cereus group bacteria.

Among the strains that possess all of the HBL genetic determinants, the NHE genes, $b c e T$ or $c y t K$, were found in both toxic as well as non-toxic strains. Therefore, as reported by Gilois et al. [66], the presence of a virulence gene does not guaranty the production and secretion of the corresponding protein. Several studies reported that the importance of the enterotoxins is determined by their expression levels and combinations, which is strain dependent. For example, deletion of the $h b l$ operon or the cytK gene in B. thuringiensis strain 407 Cry- did not affect its cytotoxicity [67], while inactivation of the $h b l$ operon in B. cereus ATCC 14579 reduced the cytotoxic and hemolytic activity [68]. After elimination of $h b l$ genes expression the $B$. thuringiensis strain still produced Nhe and CytK, while B. cereus ATCC 14579 could only rely on its low Nhe expression.

Virulence gene expression is not only influenced by the genetic characteristics of the strain, but also by environmental parameters, such as the food composition, the $\mathrm{pH}$ and the temperature. Food products with a neutral to alkaline $\mathrm{pH}$, high water and starch content and an intermediate glucose concentration pose a potential threat, as their nutrient composition stimulates enterotoxin and cereulide expression in the food and/or in the small intestine [15]. The inhibitory effect on enterotoxin production might be indirect due to growth inhibition of $B$. cereus cells. Both, mesophilic and psychrotolerant $B$. cereus can produce diarrhoeal and emetic toxins. Sometimes, more emetic toxin is strains produced at lower temperatures $\left(12-15^{\circ} \mathrm{C}\right)$ than at $30^{\circ} \mathrm{C}$ if more incubation time is granted [69]. Higher incubation temperatures $\left(30-32{ }^{\circ} \mathrm{C}\right)$ generally yield higher enterotoxin concentrations, both for psychrotrophic as mesophilic strains [59]. However, some strains show similar toxin production at high $\left(32^{\circ} \mathrm{C}\right)$ and low $\left(10^{\circ} \mathrm{C}\right)$ temperatures for cultures in BHI with similar biomass [70]. Future studies investigating the effect of environmental parameters on the expression of enterotoxin genes should be conducted by preference under conditions mimicking the human gastrointestinal environment, because the enterotoxin production in food before consumption is generally not considered a major concern. Indeed, these enterotoxins are probably completely inactivated by cooking and gastrointestinal passage because of their 
thermolability and their sensitivity to proteolytic enzymes and acid pH [15]. Moreover, Gilois et al. [66] have demonstrated that certain toxins such as CytK are unstable and do not persist more than $2 \mathrm{~h}$ in $B$. cereus group culture supernatants. Consequently, further studies should be undertaken to assess the expression as well as the stability of the toxins after secretion.

The antibiotic susceptibility of bacteria is a public health concern. Our study has shown that B. cereus group strains exhibited various degrees of susceptibility against the antimicrobial agents tested. The majority of the studied strains was resistant to ampicillin, which is in good agreement with previous studies showing a high resistance of this group to ß-lactam antimicrobials [71-73]. This last property may be correlated to the ability of the strains to synthesis $ß$-lactamase, enzymes involved in the degradation of the antibiotic [73]. In B. cereus group, the production of $\beta$-lactamases can lead to resistance even up to the third generation of cephalosporins [74]. Eightyeight percent of strains were resistant to novobiocin. While, Aklilu et al. [26] showed that all the B. cereus group isolates they tested showed resistance toward Novobiocin.

Ampicillin and Novobiocin are widely used in the animal production in Tunisia. Ampicillin is used in the treatment of septicaemias, respiratory and urinary tract infections. It was very important in the treatment of many diseases in a broad range of animal species. Few economical alternatives are available. Novobiocin is used in the treatment of mastitis in the form of intramammary creams. The indiscriminate use of such antimicrobial agents in animal husbandry has been linked to the development and spread of resistant bacteria into the environment and their further transmission to humans via the food chain could lead to serious consequences on public health [75]. In addition, there are also human health concerns about the presence of antimicrobial residues in animal products [76]. With the emergence of antimicrobial resistance, the pathogenicity and virulence of these organisms have increased and treatment options are diminishing and also more expensive. More than $85 \%$ of the studied strains were sensitive to tetracyclin. This value is more or less consistent with those reported in literature. Arslan et al. [77] reported, for a collection of 29 B. cereus group strains, a susceptibility of $89.7 \%$ of the strains to tetracyclin. Conversely, Ankolekar et al. [27] found a resistance to tetracycline in $98 \%$ of the tested strains. Since B. cereus group bacteria are widespread foodborne pathogens, it is important to emphasize that antimicrobial susceptibility testing allows to screen effective antibiotics that warrant therapy in cases of foodborne illness.

The evaluation of the antimicrobial susceptibility of $B$. cereus group bacteria to a variety of antibiotics allows a better control of these bacteria when they are involved in infectious diseases and subsequently a better protection of human health. In our study, susceptibility to the ciprofloxacin was shown in all the isolates from food. Similar to this, Banerjee et al. (2001) [78] received $100 \%$ sensitivity to cipro-floxacin in samples from patients, and other authors obtained the same result in testing sensitivity to ciprofloxacin in samples from food [74, 79]. Sensitivity to ciprofloxacin is confirmed by Jensen et al. (2001) [80] in B. cereus strains isolated from agricultural soil in Denmark. Therefore, these data demonstrated that ciprofloxacin is relatively effective against $B$. cereus group strains from different sources as single agent.

\section{Conclusion}

This is the first report which assesses the toxigenic potential of $B$. cereus group strains isolated from different food matrices in Tunisia. This study evaluates the sanitary risk potential of $B$. cereus group strains by detecting and profiling virulence genes, as well as by testing their cytotoxic activity on Caco- 2 cells and their antimicrobial susceptibility. The results showed that this $B$. cereus group collection has a significant toxigenic potential and could become problematic. In order to prevent food poisoning due to this microorganism, further studies could be devoted to the evaluation of the cytotoxicity potential of the strains in more complex microbial environments such as food products stored under different conditions.

\section{Abbreviations}

BceT: Enterotoxin T; BHI-YE: Brain Heart Infusion +Yeast Extract; ces: cereulide synthetase gene; CFU: Colony-forming unit; CLSI: Clinical and Laboratory Standards Institute; CytK: Cytotoxin K; DNA: deoxyribonucleic acid; HBL: Hemolysin BL; NHE: Non-Hemolytic Enterotoxin; PBS: Phosphate Buffered Saline; PCR: Polymerase Chain Reaction; PHE: Public Health England

\section{Acknowledgements}

This work is part of a doctoral thesis by Maroua GDOURA-BEN AMOR. The authors are grateful to all collaborators in this study.

\section{Authors' contributions \\ MG-B: conception and design of the work and writing of the manuscript; SJ and FB: interpretation of the data, writing, and review of the manuscript; NG and $A C$ : acquisition, analysis, and interpretation of data; RG: contribution to the writing and review; MG and CT: supervision of the project, important intellectual contributions and final approval of the version to be published. All authors have read and approved the manuscript.}

\section{Funding}

This research received no specific grant from any funding agency in the public, commercial, or not-for-profit sectors.

Availability of data and materials

All data generated or analyzed during this study are included in this published article.

Ethics approval and consent to participate Not applicable. 


\section{Consent for publication}

Not applicable.

\section{Competing interests}

The authors declare that they have no competing interests.

\section{Author details}

'Laboratory Research of Toxicology-Microbiology Environmental and Health LR17ES06, Sciences Faculty of Sfax, University of Sfax, Sfax, Tunisia. ${ }^{2}$ Equipe Microbiologie, Agrocampus Ouest, INRA, UMR1253 Science et Technologie du Lait et de I'CEuf, Rennes, France. ${ }^{3}$ Mixscience, Rue des Courtillons, ZAC Cissé Blossac, 35712 Bruz, France.

Received: 21 March 2019 Accepted: 14 August 2019

Published online: 24 August 2019

\section{References}

1. Granum PE. Bacillus cereus and its toxins. J Appl Microbiol. 1994;76:61-6.

2. Bennett SD, Walsh KA, Gould HA. Foodborne disease outbreaks caused by Bacillus cereus, Clostridium perfringens, and Staphylococcus aureus-United States, 1998-2008. Clin Infect Dis. 2013;57:425-33.

3. Dierick K, Van Coillie E, Swiecicka I, Meyfroidt G, Devlieger $H$, Meulemans A, Hoedemaekers G, Fourie L, Heyndrickx M, Mahillon J. Fatal family outbreak of Bacillus cereus associated food poisoning. J Clin Microbiol. 2005;43:4277-9.

4. Haeghbaert S, Le Querrec F, Bouvet P, Gallay A, Espie E, Vaillant V. Les toxiinfections alimentaires collectives en France en 2001. Bull Epidemiol Hebd. 2002;50:249-54.

5. Mahler H, Pasi A, Kramer JM, Schulte P, Scoging AC, Bär W, Krähenbühl S. Fulminant liver failure in association with the emetic toxin of Bacillus cereus. N Engl J Med. 1997;336:1142-8.

6. Stenfors Arnesen LP, Fagerlund A, Granum PE. From soil to gut: Bacillus cereus and its food poisoning toxins. FEMS Microbiol Rev. 2008;32:579-606.

7. Ceuppens S, Rajkovic A, Hamelink S, Van de Wiele T, Boon N, Uyttendaele M. Enterotoxin production by Bacillus cereus under gastrointestinal conditions and their immunological detection by commercially available kits. Foodborne Pathog Dis. 2012;9:1130-6.

8. Hwang JY, Park JH. Survival and growth of Bacillus cereus group and presumptive Cronobacter spp. contaminated naturally in rehydrated Sunsik. Food Sci Biotechnol. 2010;19:1683-7.

9. Zhang Z, Feng L, Xu H, Liu C, Shah NP, Wei H. Detection of viable enterotoxin-producing Bacillus cereus and analysis of toxigenicity from ready to- eat foods and infant formula milk powder by multiplex PCR. J Dairy Sci. 2015;99:1047-55

10. Castiaux V, Liu X, Delbrassinne L, Mahillon J. Is Cytotoxin K from Bacillus cereus a bona fide enterotoxin? Int J Food Microbiol. 2015;211:79-85.

11. Guinebretiere MH, Fagerlund A, Granum PE, Nguyen-The C. Rapid discrimination of cytK-1 and cytk-2 genes in Bacillus cereus strains by a novel duplex PCR system. FEMS Microbiol Lett. 2006;259:74-80.

12. Agata N, Ohta M, Arakawa Y, Mori M. The bceT gene of Bacillus cereus encodes an enterotoxic protein. Microbiology. 1995;141:983-8.

13. Choma C, Granum PE. The enterotoxin T (BceT) from Bacillus cereus can probably not contribute to food poisoning. FEMS Microbiol Lett. 2002; 217:115-9.

14. Hansen BM, Høiby PE, Jensen GB, Hendriksen NB. The Bacillus cereus BceT enterotoxin sequence reappraised. FEMS Microbiol Lett. 2003;223:21-4.

15. Ceuppens S, Rajkovic A, Heyndrickx M, Tsilia V, Wiele TVD, Boon N Uyttendaele M. Regulation of toxin production by Bacillus cereus and its food safety implications. Crit Rev Microbiol. 2011;1:1-26.

16. Granum PE, O'sullivan K, Lund T. The sequence of the non-haemolytic enterotoxin operon from Bacillus cereus. FEMS Microbiol Lett. 1999; 177:225-9.

17. Hendriksen NB, Hansen BM, Johansen JE. Occurrence and pathogenic potential of Bacillus cereus group bacteria in a sandy loam. Antonie Van Leeuwenhoek. 2006;89:239-49.

18. Lund T, De Buyser ML, Granum PE. A new cytotoxin from Bacillus cereus that may cause necrotic enteritis. Mol Microbiol. 2000;38:254-61.

19. Granum PE. Bacillus cereus. In: Doyle MP, editor. Food microbiology: fundamentals and Frontiers. Washington: ASM Press; 2001. p. 373-81.
20. Kramer JM, Gilbert RJ. Bacillus cereus and other Bacillus species. In: Doyle MP, editor. Foodborne bacterial pathogens. New York: Marcel Dekker; 1989. p. 21-70.

21. Public Health England (PHE). Guidelines for Assessing the Microbiological Safety of Ready-to-Eat Foods Placed on the Market. 2009. https://www.gov. uk/government/publications/ready-to-eat-foods-microbiological-safetyassessment-guidelines.

22. Castiaux V, Laloux L, Schneider YJ, Mahillon J. Screening of Cytotoxic B. cereus on Differentiated Caco-2 Cells and in Co-Culture with MucusSecreting (HT29-MTX). Cells Toxins. 2016;8:1-20.

23. Choma C, Guinebretière MH, Carlin F, Schmitt P, Velge P, Granum PE, Ngyyen-The C. Prevalence, characterization and growth of Bacillus cereus in commercial cooked chilled foods containing vegetables. J Appl Microbiol. 2000;88:617-25.

24. Jan S, Brunet N, Techer C, Le Marechal C, Kone AZ, Grosset N, Cochet MF, Gillard A, Gautier M, Puterflam J, Baron F. Biodiversity of psychrotrophic bacteria of the Bacillus cereus group collected on farm and in egg product industry. Food Microbiol. 2011;28:261-5.

25. Stenfors $L P$, Mayr R, Scherer S, Granum PE. Pathogenic potential of fifty Bacillus weihenstephanensis strains. FEMS Microbiol Lett. 2002;215:47-51.

26. Aklilu E, Tukimin E, Daud NHA, Kyaw T. Enterotoxigenic Bacillus cereus from cooked chicken meat: a potential public health hazard. Malays J Microbiol. 2016;12:112-5.

27. Ankolekar C, Rahmati T, Labbé RG. Detection of toxigenic Bacillus cereus and Bacillus thuringiensis spores in U.S. rice. Int J Food Microbiol. 2009;128:460-6.

28. Fernandes MS, Schneid GFI, Kabuki DY, Kuaye AY. Enterotoxigenic profile, antimicrobial susceptibility, and biofilm formation of Bacillus cereus isolated from ricotta processing. Int Dairy J. 2014;38:16-23.

29. Yibar A, Çetinkaya F, Soyutemiz E, Yaman G. Prevalence, enterotoxin production and antibiotic resistance of Bacillus cereus isolated from milk and cheese. Kafkas Univ Vet Fak Der. 2017;23:635-42.

30. Gdoura-Ben Amor M, Siala M, Zayani M, Grosset N, Smaoui S, MessadiAkrout F, Baron F, Jan S, Gautier M, Gdoura R. Isolation, identification, prevalence, and genetic diversity of Bacillus cereus group Bacteria from different foodstuffs in Tunisia. Front Microbiol. 2018;9:447. https://doi.org/1 0.3389/fmicb.2018.00447.

31. Kim K, Seo J, Wheeler K, Park C, Kim D, Park S, Kim W, Chung SI, Leighton T. Rapid genotypic detection of Bacllus anthracis and the Bacillus cereus group by multiplex real time PCR melting curve analysis. FEMS Pathog Dis. 2005; 43:301-10.

32. Walsh PS, Metzger DA, Higuchi R. Chelex 100 as a medium for simple extraction of DNA for PCR-based typing from forensic material. Biotechniques. 1991;10:506-13.

33. Guinebretière $M H$, Broussolle $V$, Nguyen-The $C$. Enterotoxigenic profiles of food-poisoning and food-borne Bacillus cereus strains. J Clin Microbiol. 2002 40:3053-6.

34. Ehling-Schulz M, Fricker M, Scherer S. Identification of emetic toxin producing Bacillus cereus strains by a novel molecular assay. FEMS Microbiol Lett. 2004;232:189-95.

35. Ehling-Schulz M, Vukov N, Schulz A, Shaheen R, Andersson M, Märtlbauer E, Scherer S. Identification and partial characterization of the nonribosomal peptide synthetase gene responsible for cereulide production in emetic Bacillus cereus. Appl Environ Microbiol. 2005:71:105-13.

36. Techer C, Baron F, Delbrassinne L, Belaid R, Brunet N, Gillard A, Gonnet F, Cochet MF, Grosset N, Gautier M, Andjelkovic M, Lechevalier V, Jan S. Global overview of the risk linked to the Bacillus cereus group in the egg product industry: identification of food safety and food spoilage markers. J Appl Microbiol. 2014;116:1344-58

37. Bauer AW, Kirby WM, Sherris JC, Turck M. Antibiotic susceptibility testing by a standardized single disk method. Am J Clin Pathol. 1966;45:493-6.

38. CLSI. Clinical and laboratory standards institute (CLSI). Performance standards for antimicrobial susceptibility testing; approved twentieth informational supplement M 100-S20. Wayne: CLSI; 2010.

39. Tewari A, Singh SP, Singh R. Incidence and enterotoxigenic profile of Bacillus cereus in meat and meat products of Uttarakhand, India. J Food Sci Technol. 2015:52:1796-801.

40. Wehrle E, Moravek M, Dietrich R, Bürk C, Didier A, Märtlbauer E. Comparison of multiplex PCR, enzyme immunoassay and cell culture methods for the detection of enterotoxigenic Bacillus cereus. J Microbiol Methods. 2009;78:265-70.

41. Zhou G, Zheng D, Dou L, Cai Q, Yuan Z. Occurrence of psychrotolerant Bacillus cereus group strains in ice creams. Int J Food Microbiol. 2010;137:143-6. 
42. Ngamwongsatit $P$, Buasri $W$, Pianariyanon P, Pulsrikarn C, Ohba M, Assavanig A, Panbangred W. Broad distribution of enterotoxins genes ( $h b / C D A$, nheABC, cytK and entFM) among Bacillus thuringiensis and Bacillus cereus as shown by novel primers. Int J Food Microbiol. 2008;121:352-6.

43. Lee N, Kim MD, Chang HJ, Choi SW, Chun HS. Genetic diversity, antimicrobial resistance, toxin gene profiles, and toxin production ability of Bacillus cereus isolates from doenjang, a Korean fermented soybean paste. J Food Saf. 2017, 2017. https://doi.org/10.1111/jfs.12363.

44. Chon JW, Kim JH, Lee SJ, Hyeon JY, Seo KH. Toxin profile, antibiotic resistance, and phenotypic and molecular characterization of Bacillus cereus in Sunsik. Food Microbiol. 2012;32:217-22.

45. Aragon-Alegro LC, Palcich G, Volz-Lopes G, Ribeiro VB, Landgraf M, Destro MT. Enterotoxigenic and genetic profiles of Bacillus cereus strains of food origin in Brazil. J Food Prot. 2008;71:2115-8.

46. Bonerba E, Di Pinto A, Novello L, Montemurro F, Terio V, Colao V, Ciccarese G, Tantillo G. Detection of potentially enterotoxigenic food-related Bacillus cereus by PCR analysis. Int J Food Sci Technol. 2010;45:1310-5.

47. Yang IC, Shih DY, Huang TP, Huang YP, Wang JY, Pan TM. Establishment of a novel multiplex PCR assay and detection of toxigenic strains of the species in the Bacillus cereus group. J Food Prot. 2005;68:2123-30.

48. Agata N, Ohta M, Yokoyama K. Production of Bacillus cereus emetic toxin (cereulide) in various foods. Int J Food Microbiol. 2002;73:23-7.

49. Naranjo M, Denayer S, Botteldoorn N, Delbrassinne L, Veys J, Waegenaere J, Sirtaine N, Driesen RB, Sipido KR, Mahillon J, Dierick K. Sudden death of a young adult associated with Bacillus cereus food poisoning. J Clin Microbiol. 2011:49:4379-81.

50. López A, Minnaard J, Pérez P, Alippi A. A case of intoxication due to a highly cytotoxic Bacillus cereus strain isolated from cooked chicken. Food Microbiol. 2015;46:195-9

51. Messelhäusser U, Frenzel E, Blöchinger C, Zucker R, Kämpf P, Ehling-Schulz M. Emetic Bacillus cereus are more volatile than thought: recent foodborne outbreaks and prevalence studies in Bavaria (2007-2013). Biomed Res Int. 2014;2014:465603. https://doi.org/10.1155/2014/465603.

52. Hariram U, Labbé R. Spore prevalence and toxigenicity of Bacillus cereus and Bacillus thuringiensis isolates from U.S. retail spices. J Food Prot. 2015;78:590-6.

53. Fogele B, Granta R, Valcina O, Bērzinšs A. Occurrence and diversity of Bacillus cereus and moulds in spices and herbs. Food Control. 2018:83:69-74.

54. Granum PE. Bacillus cereus. In: Doyle MP, Beuchat LR, editors. Food microbiology: fundamentals and frontiers. Washington: ASM Press; 2007. p. 440-56.

55. Yang $Y$, Gu H, Yu X, Zhan L, Chen J, Luo Y, Zhang Y, Zhang Y, Lu Y, Jiang J, Mei L. Genotypic heterogeneity of emetic toxin producing Bacillus cereus isolates from China. FEMS Microbiol Lett. 2017;364. https://doi.org/10.1093/ femsle/fnw237.

56. Kim JB, Kim JM, Kim SY, Kim JH, Park YB, Choi NJ, Oh DH. Comparison of enterotoxin production and phenotypic characteristics between emetic and Enterotoxic Bacillus cereus. J Food Prot. 2010;73:1219-24.

57. Rahmati T, Labbe R. Levels and toxigenicity of Bacillus cereus and Clostridium perfringens from retail seafood. J Food Prot. 2008;71:1178-85.

58. Carlin F, Fricker M, Pielaat A, Heisterkamp S, Shaheen R, Salonen MS, Svensson B, Nguyen-the C, Ehling-Schulz M. Emetic toxin producing strains of Bacillus cereus show distinct characteristics within the Bacillus cereus group. Int J Food Microbiol. 2006;109:132-8.

59. Baron F, Cochet MF, Grosset N, Madec MN, Briandet R, Dessaigne S, Chevalier S, Gautier M, Jan S. Isolation and characterization of a psychrotolerant toxin producer, Bacillus weihenstephanensis, in liquid egg products. J Food Prot. 2007;70:2782-91.

60. Dietrich R, Fella C, Strich S, Märtlbauer E. Production and characterization of monoclonal antibodies against the hemolysin BL enterotoxin complex produced by Bacillus cereus. Appl Environ Microbiol. 1999;65:4470-4.

61. Dietrich R, Moravek M, Bürk C, Granum PE, Märtlbauer E. Production and characterization of antibodies against each of the three subunits of the $B$. cereus non hemolytic enterotoxin complex. Appl Environ Microbiol. 2005;71:8214-20.

62. Prüss BM, Dietrich $R$, Nibler B, Märtlbauer $E$, Scherer $S$. The hemolytic enterotoxin $\mathrm{HBL}$ is broadly distributed among species of the Bacillus cereus group. Appl Environ Microbiol. 1999;65:5436-42.

63. Moravek M, Dietrich R, Buerk C, Brousolle V, Guinebretière MH, Granum PE, Nguyen-the C, Martlbauer E. Determination of the toxic potential of Bacillus cereus isolates by quantitative enterotoxin analyses. FEMS Microbiol Lett. 2006:257:293-8.

64. Jeßberger N, Krey V, Rademacher C, Böhm M, Mohr A, Ehling-Schulz M, Scherer S, Märtlbauer E. From genome to toxicity: A combinatory approach highlights the complexity of enterotoxin production in B. cereus. Front Microbiol. 2015;6:560. https://doi.org/10.3389/fmicb.2015.00560.

65. Miller RA, Jian J, Beno SM, Wiedmann M, Kovac J. Intraclade Variability in Toxin Production and Cytotoxicity of Bacillus cereus Group Type Strains and Dairy-Associated Isolates. Appl Environ Microbiol. 2018;84. https://doi.org/1 0.1128/AEM.02479-17.

66. Gilois N, Ramarao N, Bouillaut L, Perchat S, Aymerich S, Nielsen-Leroux C, Lereclus D, Gohar M. Growth-related variations in the B. cereus secretome. Proteomics. 2007;7:1719-28.

67. Ramarao N, Lereclus D. Adhesion and cytotoxicity of Bacillus cereus and Bacillus thuringiensis to epithelial cells are FlhA and PICR dependent, respectively. Microbes Infect. 2006;8:1483-91.

68. Lindbäck T, Okstad OA, Rishovd AL, Kolsto AB. Insertional inactivation of hblC encoding the L2 component of Bacillus cereus ATCC 14579 haemolysin $B L$ strongly reduces enterotoxigenic activity, but not the haemolytic activity against human erythrocytes. Microbiology. 1999;145:3139-46.

69. Finlay WJJ, Logan NA, Sutherland AD. Bacillus cereus produces most emetic toxin at lower temperatures. Lett Appl Microbiol. 2000;31:385-9.

70. Fermanian C, Lapeyre C, Fremy JM, Claisse M. Diarrhoeal toxin production at low temperature by selected strains of Bacillus cereus. J Dairy Res. 1997;64:551-9.

71. Andrews JM, Wise R. Susceptibility testing of Bacillus species. J Antimicrob Chemother. 2002;49:1040-2.

72. Lee N, Sun JM, Kwon KY, Kim HJ, Koo M, Chun HS. Genetic diversity, antimicrobial resistance, and toxigenic profiles of Bacillus cereus strains isolated from sunsik. J Food Prot. 2012;75:225-30.

73. Park YB, Kim JB, Shin SW, Kim JC, Cho SH, Lee BK, Ahn J, Kim JM, Oh $\mathrm{DH}$. Prevalence, genetic diversity, and antibiotic susceptibility of Bacillus cereus strains isolated from rice and cereals collected in Korea. J Food Prot. 2009;72:612-7

74. Özcelik B, Citak S. Evaluation of antibiotic resistance of Bacillus cereus isolates in ice-cream samples sold in Ancara. Turk J Pharm Sci. 2009; 6(3):231-8.

75. Apata DF. Antibiotic resistance in poultry. Int J Poult Sci. 2009;8:404-8.

76. Addo KK, Mensah Gl, Aning KG, Nartey N, Nipah GK, Bonsu C, Akyeh ML Smits HL. Microbiological quality and antibiotic residues in informally marketed raw cow milk within the coastal savannah zone of Ghana. Tropical Med Int Health. 2011:16:227-32.

77. Arslan S, Eyi A, Küçüksari R. Toxigenic genes, spoilage potential and antimicrobial resistance of Bacillus cereus group strains from ice cream. Anaerobe. 2014;25:42-6.

78. Banerjee M, Nair GB, Ramamurthy T. Phenotypic \& genetic characterization of Bacillus cereus isolated from the acute diarrhoeal patients. Indian J Med Res. 2011:133:88-95.

79. Oladipo IC, Adejumobi OD. Incidence of antibiotic resistance in some bacterial pathogens from street vended food in Ogbomoso, Nigeria. Park J Nutr. 2010;9(11):1061-8.

80. Jensen LB, Baloda S, Boye M, Aarestrup FM. Antimicrobial resistance among Pseudomonas spp. and the Bacillus cereus group isolated from Danish agricultural soil. Environ Int. 2001;26(7-8):581-7.

\section{Publisher's Note}

Springer Nature remains neutral with regard to jurisdictional claims in published maps and institutional affiliations. 